\title{
NEKRASOV COSSACKS' FESTIVE CLOTHES: HISTORICAL CHANGES AND MODERN FUNCTIONS
}

\author{
Nina Vlaskina
}

\begin{abstract}
The Nekrasov Cossacks (or Nekrasovites) are an ethno-religious group remarkable for preserving their ancestors' heritage, especially the traditional costume, cuisine, and songs. Led by their ataman Ignat Nekrasov, in the 18th century, a group of the Cossack Old Believers left Russia to escape from religious and political persecution. For 250 years, they lived outside of their historical homeland and maintained limited contact with other ethnic groups. They returned to Russia in the 20th century.

This paper will study the transformation of Nekrasov Cossacks' costumes through the last two centuries, analyzing the contemporary use of the Cossack national costume on festive occasions, and interpreting the role of the Cossack national costume in heritage preservation processes. I will analyze the data derived from ethnographic and dialectological studies as well as my own ethnolinguistic field research in the Krasnodar and Stavropol krays (regions) in Russia.

The paper will focus on a depiction of the typical Nekrasov Cossack costume and the functional hierarchy of its elements; the declared immutability of the traditional costume vs. its actual transformations and reasons for those transformations; the modern functions of the Nekrasovites' costume as a symbol of identity for the members of the group, as well as a mass media stereotype.
\end{abstract}

Keywords: cultural dynamics, heritage, identity, Nekrasov Cossacks, Old Believers, traditional costume

\section{INTRODUCTION}

The Nekrasov Cossacks are an ethno-religious group remarkable for preserving their ancestors' heritage, especially traditional costume, food, and songs. Led by their ataman Ignat Nekrasov, in the 18th century, a group of the Cossack Old Believers left Russia, escaping from religious and political persecution. For 250 years, they lived outside of their historical homeland - primarily in Turkey and Romania - and maintained limited contacts with other ethnic groups. In the 20 th century, they returned to Russia in several waves of migration.

The Nekrasov Cossacks' costume is connected with the history of this ethnoreligious group. The formation of Cossack society began in the Don region in 
the south of Russia. In the 16th and 17th centuries, this area was populated by groups from different provinces of southern Russia. A variety of factors led to the emergence of a specific regional variant of culture, combining ethnic peculiarities (the southern Russian and Ukrainian elements with some traits of the steppe nomadic Turkic cultures) and social ones (the Cossacks were, first and foremost, warriors). These factors included: life on the frontier, constant participation in military campaigns, emphasizing the value system of the male community, and the long-term coexistence of different ethnic groups in the same territory. While emigrating to Turkey in the late 18th century, after the rebellion of Kondraty Bulavin and his supporters, Cossack Old Believers, followers of Ignat Nekrasov, were already carriers of this specific type of culture. Accordingly, this group of Cossacks had clothes with elements peculiar to the southern Russian and Ukrainian costume.

In this article, I will briefly characterize the festive (worn primarily on weekends, calendrical festivals, for church services and weddings) and everyday traditional clothing of the Nekrasov Cossacks. I will focus on the main aspects of the transformation of traditional and festive clothing in the Turkish period, and after the Nekrasov Cossacks' return to the USSR (in the 1910s-1920s and in 1962); I will also show how the clothes (festive clothes mainly) became the spokesperson of the ideas of national identity and cultural heritage. I will show this process within the group, at the level of the members of the community, at the level of local institutions, and groups from outside.

The description of the costume and its use is based on the analysis of the ethnographic and dialectological publications, and expedition data collected by the researchers of the Southern Federal University and the Institute for Social and Economic Research and Humanities of the Southern Scientific Centre of the Russian Academy of Sciences in 2007-2016 among the Nekrasov Cossacks in two regions of Russia: Krasnodar kray and Stavropol kray. I also used descriptions of 19th-century travelers and historical and ethnographic studies of the subject.

\section{THE MAIN ELEMENTS OF NEKRASOV COSSACKS' COSTUME AND PARALLELS IN THE NEIGHBORING CULTURES}

The first descriptions of Nekrasov Cossack clothes come from the English travelers William Hamilton (1842: 105-106) and Charles Mac Farlane (1850: 292), and were written in the middle of the 19th century. In the second half of the 19th and the early 20th centuries, several Slavic travelers and ethnographers wrote about the Nekrasovites' everyday and festive costumes. They were Vasily Kelsiev (Ivanov-Zheludkov) (1866: 414, 424, 429, 437), V. Shchepotiev (1895: 
562-583), Iakov Smirnov (1896: 9, 12, 29), Mikhail Ganko (Mainosskie kazaki 1899: 106), and Vladimir Minorsky (1902: 57-58).

Even a century ago, from the point of view of the authors mentioned above, the traditional dress was a representation of the Nekrasovites' identity and an evidence of their Russian origin. William Hamilton wrote, "The inhabitants still preserve their language and their dress" (Hamilton 1842: 105). In a similar homeward-looking vein, Ivanov-Zheludkov said, "The embroidery pattern of these shirts reminded me a lot of the drawings on our jars, on the old manuscript miniatures and the details of the Saint Basil's Cathedral" (Ivanov-Zheludkov 1866: 429). In a comment that well represents this viewpoint, the author of Mainosskie kazaki wrote, "All of them preserved their Cossack type and their folk dress" (Mainosskie kazaki 1899: 105).

Soviet and recent ethnographic expeditions to the Nekrasovites - who returned to Russia and settled in Krasnodar kray starting in 1920 and later, and in Stavropol kray in 1962 and later - made a detailed scientific description of the Nekrasovites' clothes possible. The most complete information about it can be found in the articles of Lydia Zhukova and Svetlana Bandurina (1986), Tatiana Abramova (1997; 2009), and Viktoria Lipinskaya (2011). Patricia White Johnson carried out a study of dress and acculturation among the Russian Old Believers in Oregon with several pages about the costume of the Nekrasovites (Johnson 1983: 49-51), a small party of whom went from Turkey to the USA at the same time that the majority moved to the USSR.

I supplemented this source base with my field materials and lexical data from the Dictionary of the Dialect of the Nekrasov Cossacks (Serdiukova 2005) to highlight the dynamic processes in the development of the festive and everyday clothes of this Russian ethno-confessional enclave.

The traditional complex of male clothes in the 19th century consisted of a shirt and pants, made of homespun cloth. The cut of the shirt was of tunic type with a straight cut in the front, without a collar, with long straight sleeves gathered at the wrists. The upper part of the shirt had an inner layer and rectangular pieces of cloth inserted under the arms. The cuffs and hem had a red border. Festive shirts were richly embroidered round the neck and down the breast and sometimes on the sleeves (in case of the so-called round shirtkrugounaia rubakha (Serdiukova 2005: 248)).

The abundance and importance of the embroidery traditions for the Nekrasovites can be proved by their special lexicon of this handicraft: there are about ten dialectal words naming the types of stitches and embroidery patterns (Serdiukova 2005: 42, 118, 121, etc.). The embroidered elements were distinctive features of the festive clothes. The blue or red-colored pants were made of unbleached linen in summer and of wool cloth in winter. The wearing style of 


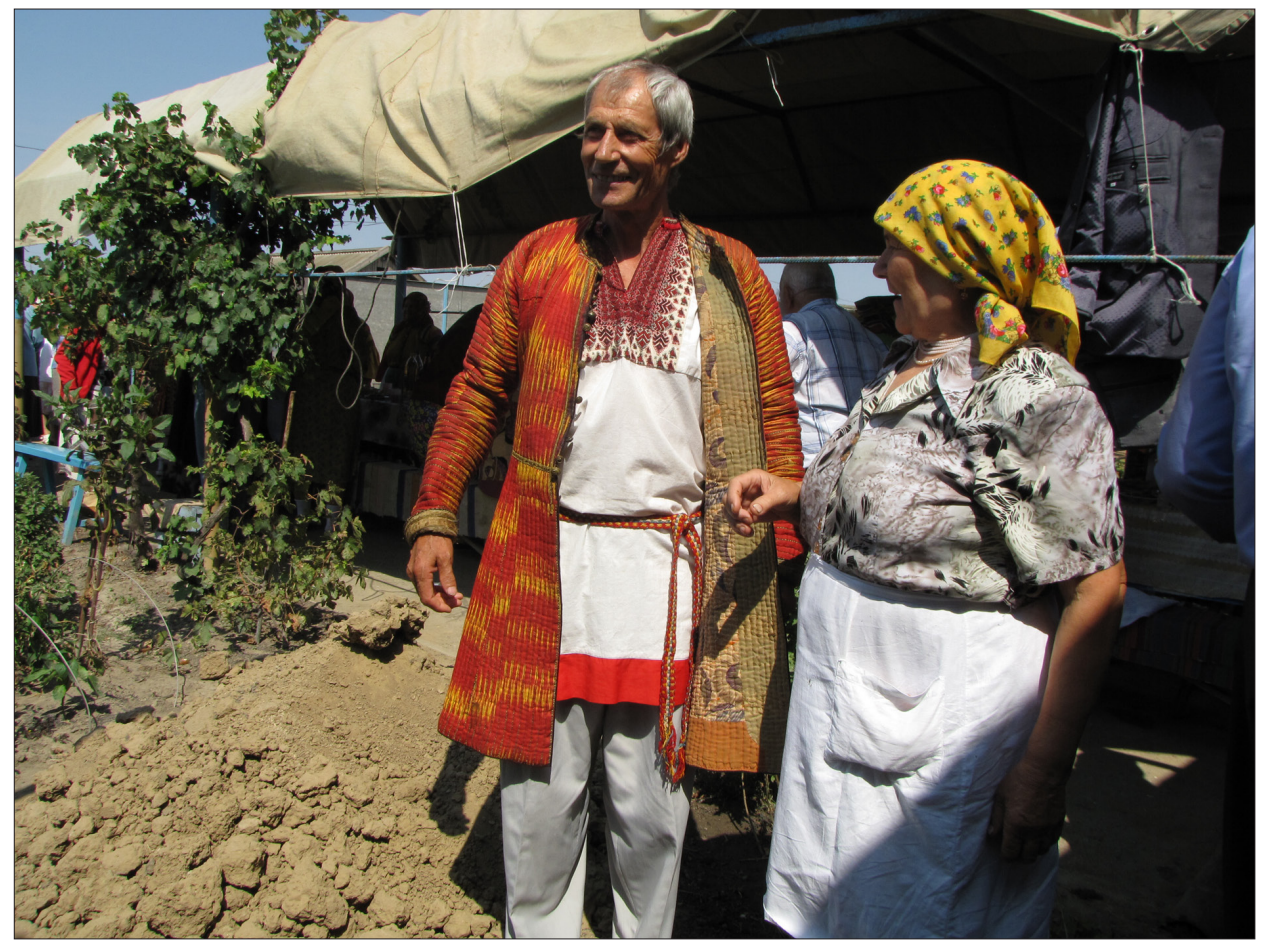

Figure 1. Nekrasov Cossack in the traditional embroidered shirt and beshmet on the patronal feast (the Assumption) in the Novokumskii village, Stavropol kray, Russia. Photograph by Nina Vlaskina 2010.

these shirts was similar to the Russian fashion, with the shirt hanging over the trousers. In order to spare expensive material, Cossacks could make the upper part of the pants of cheaper white material. The cut of the pants was Russian, but the pants had expanding inserts, similar to the Don Cossacks' ones (Lipinskaya 2011: 396). The headgear of men was a high lambs-wool hat and, at the end of the 19th century, a straw hat.

The Nekrasovites had three types of male overdress. In the wintertime the Cossacks wore a fur coat. Another type of male overdress was beshmet (it had a straight cut with a stand-up collar, long narrow sleeves, and a lining made of fur or cloth, sometimes with cuts on the hips, and was made of silk or halfsilk of red and yellow color or with black stripes). This type of clothing has equivalents both in Russian and in Turkic traditions. The last type of male overdress was chekmen' (an overcoat made of homemade cloth); the same type was characteristic of the Don Cossack costume and even became a part of the Cossack military uniform in the 19th century (Fradkina \& Novak 1986: 35). 
Apart from festive and everyday clothes, the Nekrasovites had a few variants of workwear, all fit for fishing, which was the main occupation of the Cossacks, especially in the early period. The workwear included a special shirt convenient for the work in reeds (kamysheika), a cloth jacket (karapan), a leather apron (zapon), a fur coat covered with cloth (katlama), and also fishing footwear that consisted of high boots and plain shoes (chiriki).

A belt is a special part of the Old Believers' costume. ${ }^{1}$ Nekrasov Cossacks had different types of belts, which may have had several possible origins. At the early stage of their history, the Don Cossacks' costumes had multiple variants (Sukhorukov 1892: 33), because they wore costumes obtained in the campaigns against the Turks, Circassians, and others. For example, a Don historian, Vasily Sukhorukov, mentioned the Turkish silk sashes used by the Don Cossacks. The Nekrasov Cossacks who emigrated from the Don area to Turkey wore the same type of belt with a peculiar name, trubulus, which Alexander Novik and Andrey Sobolev derive from Turkish Tarabulos - the city of Tripoli, a wellknown textile center in that period of time. ${ }^{2}$ They also note the existence of this belt in the Balkans with a word of that origin in Serbian and Bulgarian. Apart from it, the Nekrasovites wore two other types of belt: vushkar (a lace or a fabric belt which may be used to keep the trousers up), and cheres (a special fabric belt with a pocket to keep money). Both of these belts were used by the Don Cossacks and had respective designations in the Don dialect (BTS 2003: $548-549,574)$. These belts have different functions, and that may be one more reason for them to exist in parallel.

The women's costume consisted of a shirt (rubakha), a kind of an overcoat (balakhon), and an apron (zaveska). The shirt had the cut of a Russian type but the distribution of materials was different. The Nekrasov Cossacks made the upper part of the shirt of a cheaper material, because it was covered by an overcoat. The bottom of it was made of two rectangular pieces of material with gores on the sides (Lipinskaya 2011: 398). The women's shirt also had a red border (like the men's shirt). The cut of the burial dress differed from the everyday shirt because it was made of only one piece of fabric, without the division into upper and lower parts (sutsel'naia rubakha) (Arkhipenko \& Kalinichenko 2012: 431-432). The sleeves were of two different variants. The older type of shirt was sewn with long dangling sleeves, which women wrapped around the wrist or rolled up while working. These sleeves were characteristic of the Russian fashion of the 15th-17th centuries (Maslova 1956: 614). The sleeves of the newer cut were shorter but also wide, made of one, two, or three strips of fabric of contrasting colors, with the cuffs on the wrists.

An overgarment balakhon had a tunic cut and could be made of silk (festive clothes) or cotton (everyday clothes) of different shades of red, orange, and yel- 


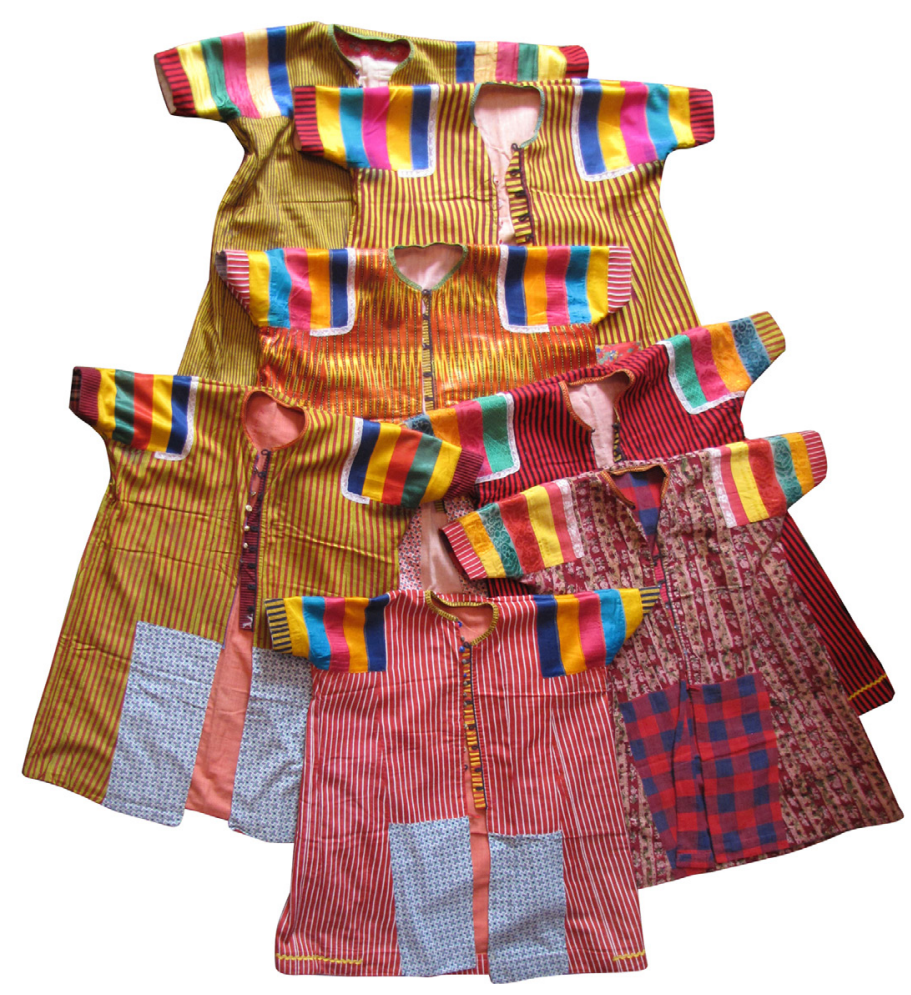

Figure 2. Different kinds of balakhon belonging to Evdokia Aralova. Brinkovskaya village, Krasnodar kray, Russia. Photograph by Nina Vlaskina 2016.

low, with black or white stripes or floral design. The sleeves were short, above the elbow, and decorated with multicolored silk ribbons (nastavochki). This is a type of decoration one can see on the shirt sleeves from the Ryazan Province in Russia (Maslova 1956: inset, Fig. 33). In the Nekrasovites' clothes, it became a part of the overgarment.

Women wore aprons made of a piece of material tucked in the belt. So the apron was an incomplete piece of the costume (Lipinskaya 2011: 398-399). From the back, the Nekrasovites tied long laces sewn from patches of contrasting colors (mutoziki) to the belt. The length of these laces differed between married women and maidens. Contrast in colors is what is considered a good combination in the costume. For example, a favorable combination could include a yellow 
shirt, an overcoat with a dominance of black, and a crimson apron. Another favorable combination could include yellow sleeves, a blue apron, a yellow or green skirt, and an overcoat with black or white stripes. As with the men's costume, women's belts have names and form similar to those of Turkish and Bulgarian origin. The wide woven Nekrasov Cossack's belt kulan matches the Ottoman belt kolan.

In the cold season, women wore warm quilted coats of the balakhon cut named sarafan; the same word is widely used in many Russian local traditions to designate a kind of dress without sleeves. Winter outerwear of Nekrasov Cossack women was flared overcoats with a stand-up collar and short sleeves, quilted with woolen or wadding fill, usually of black color (kukhaika, kukhaenka, kukhaenochka), and fur coats.

The Nekrasov Cossack women's headdress consisted of several elements and was different for festive (wedding) and everyday occasions, worn by girls and women. Girls wore fabric strips (sviazka). A headdress of a married woman consisted of several elements: they put a cloth roller (kauk) on the back of the head up to the ears, then fixed it by a long lace with a rectangular piece of cloth sewn to it (shlychka); then put a fabric strip (sviazka) over the head and covered it all with a kerchief. The latter were of bright colors (primarily red or orange), with different floral designs named by special dialectal words. There were at least two types of kerchiefs of square and rectangular form. In the latter case, the Nekrasovites sewed together two or three square kerchiefs. A woman would wrap this long shawl around her head and tuck it near her ear. The form of the resulting headdress and a dialectal designation of its part - nametka - allow drawing a parallel with the old kind of Russian towel-type headdress dating back to the 11th century and widespread in different Russian territories for a long period of time since then (Maslova 1956: 660).

Festive Nekrasov Cossack's headwear used during a wedding ceremony is analogous to the southern Russian type and consists of a cap with horns made of fabric (kichka), a hoop to be put on over the kichka, and a rectangular textile frill attached from the back (pozatyl'nik). Along with these elements, there are mentions of another type of festive headwear - kokoshnik (Serdiukova 2005: $107,125,173,272)$. The kokoshnik had a cap form and also had direct analogues in Russian tradition.

The children's costume of the Nekrasov Cossacks was quite similar to adult examples, but it lacked some details: there were no balakhons in the case of girls and beshmets in the case of small boys.

The everyday clothes of the Nekrasovites differed from the festive clothes by virtue of the material and colors used for construction. Festive clothes were made of monochromatic silk and everyday garments were made of cotton with 

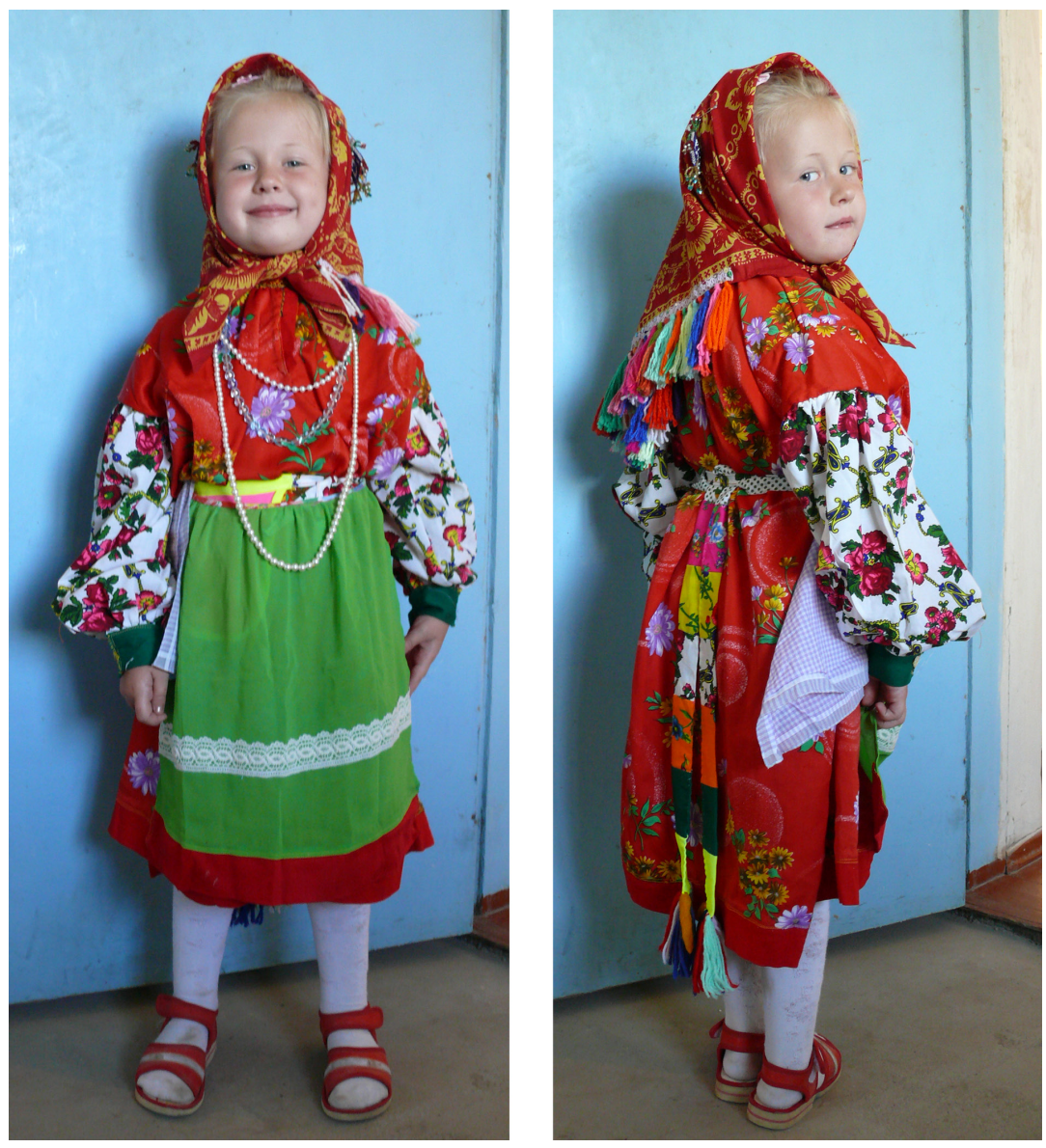

Figure 3. A girl in the traditional Nekrasovites' costume on the patronal feast (the Assumption) of the Novokumskii village, Stavropol kray, Russia. Photograph by Nataly Kalinicheva 2011.

floral pattern. The Cossacks bought fabric for their clothes in different textile centers of Asia Minor. Some of the sources for the fabrics could be figured out by analyzing the names of elements of the garments. For example, trubulus, as mentioned above, indicates purchasing textiles from Tripoli. The type of the kerchief urumenskii / urumil'skii may testify to the contacts with the European part of the Ottoman Empire - Rumelia. Mac Farlane suggested that the Nekrasovites bought fabrics in Balik Hissar (Balıkesir), which is a place where "cotton stuff [was] manufactured or sold", and "a fair of much importance in this part of Anatolia is held annually" (Mac Farlane 1850: 292). Other origins 
of textiles used by the Nekrasov Cossacks may be revealed through comparison of fabrics. Kemal Ibrahimzade and Irina Gusach showed that the Nekrasovites bought textiles produced in Tokat, a famous Turkish textile center where the hand printed textiles were produced (Ibrahimzade \& Gusach 2015). This information is indirectly confirmed by the interviews with the Nekrasovites who remember the Turks coming to the Cossack village at Lake Manyas (Kuş) to copy and then reproduce the prints of their kerchiefs and other garments. ${ }^{3}$ Also the Cossacks designate the balakhons made of Tokat fabric as old ones. As comparison showed, the fabric of the newer examples may be bought in Gaziantep, where "a woven textile with a shiny surface and colourful vertical stripes, made with silk warps (lengthwise yarns) and cotton wefts (crosswise yarns)" named Kutnu was produced. ${ }^{4}$

In spite of the Turkish influence on the Nekrasovites' clothes, which one can see through the replacement of Russian fabrics with the Turkish ones during their life in the Ottoman Empire and further on in the Turkish Republic, the design of the garments remained close to Russian types. Viktoria Lipinskaya has written about the traditional basis of the Nekrasov Cossack female costume, and has pointed out that it did not completely correlate with any known stable set of Russian women's clothing. Its characteristic features involve an unfinished, unpolished quality, including patchwork cut, non-sewed aprons, and only semi-structured everyday headdresses (Lipinskaya 2011: 401).

Explicit influences of the contacts with the Turkish and Balkan population may be seen in footwear and jewelry. Various types of the Nekrasovites' shoes have Turkish names or are spoken of as being of Turkish or Bulgarian origin. There are kalevry (sandals, Bulg. kalevra), kotyry (female shoes of rude leather, Turk. katır), kundry (male and female shoes, Turk. kundura), nadvizhki or papychi (shoes without backcloth of Turkish style, Turk. pabuc, papuc), and iarymbutiny (boots, Turk yarım). ${ }^{5}$

Metal costume decorations and jewelry put the Nekrasovites' tradition in a wider context of different cultures united in the 18th and 19th centuries under the rule of the Ottoman Empire and beyond - in the Middle East. For example, the belt with double buckles, which the Cossacks name kataur, is characteristic of the vast eastern area, including Iraq, Syria, Turkey (Taş 2015), Bulgaria (Veleva 1950: Figs. 26, 43, 46, 50), and probably other countries of the region. Metal coins (ploshchi) attached to the breast part of the Nekrasovites' female costume and elements of a headgear are present in the local variants of the national costume of Croatia (Kašpar 1987), Bulgaria (Neikova n.d.: 9; Naslednikova 1969: 95) and Montenegro. ${ }^{6}$ Different types of head jewelry made from beads or coins, which girls and women would fasten to their kerchiefs, have direct analogues in Turkish (Öğuz 2008: 137, 144, 145) and Bulgarian 


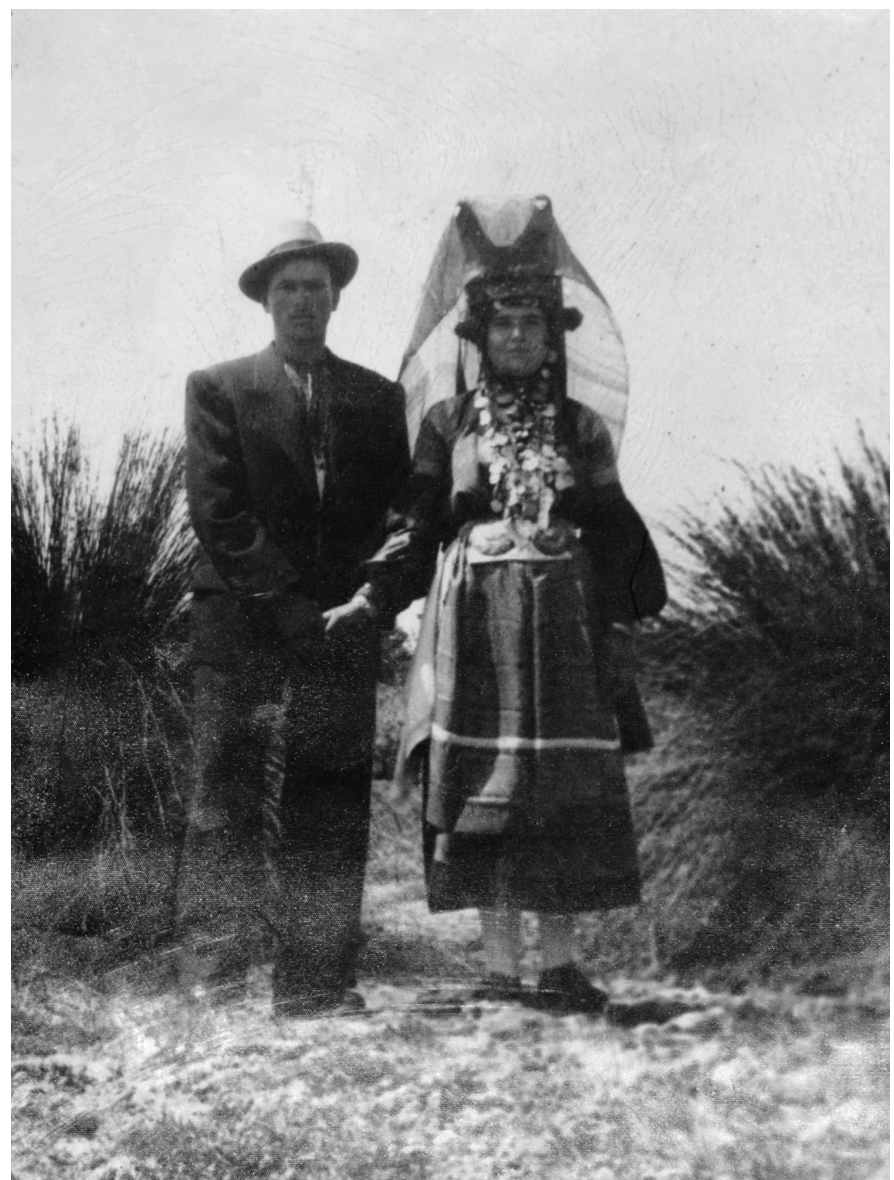

Figure 4. Nekrasov Cossacks in wedding costumes. The bride wears the traditional attire decorated with coins, a belt with round buckles, and a wedding headdress kichka. Manyas (Kocagöl) village, Turkey, 1950s. Photograph from the family archive of Domna Shkodrina.

traditions. The latter is clear from the lexical examples: in the dialect of the Nekrasov Cossacks, a word dvukhlevnichek (a coin of two Bulgarian levs) stands for a decoration of a headgear; dubla (from Bulg. duble 'rolled gold') designates a golden coin used as a decoration; the Nekrasovites' triapki ('ear-rings with small hanging elements') is derived from Bulgarian trepka, standing for "a needle with flickering and tinkling decorations" (Naslednikova 1969: 96).

While the types of metal decoration and jewelry mentioned above were adopted probably during the Nekrasovites' life in the Ottoman Empire, the decoration of the overcoat edges with big buttons may have been borrowed 
from Turkish culture earlier, most likely in the early period of the Don Cossack history, before the Cossack Old Believers emigrated to Turkey. This is proved by the fact that buttons of the same type are to be found in the descriptions of the Don Cossack costume (Sukhorukov 1892: 33).

\section{THE TRANSFORMATIONS OF THE NEKRASOVITES' COSTUME IN THE 20TH CENTURY}

During the 20th century, male, female, and children's versions of the traditional Nekrasovites' costumes were preserved to different extents. Nekrasov Cossack women lived in their village most of the time, while the men left to work (fishing primarily) in different countries, and they often visited cities. This departure from home was one of the reasons for the men to abandon traditional dress and adopt urban-style clothing, starting in the 1930s-1940s. The sorrowful decision of men to cease wearing traditional garments was reflected by the Cossacks and became a part of a manuscript chronicle written on the margins of Psalter: "In the year of 7442 (1934), the Cossacks changed the clothes of Ignat and began to shave beards, and women kept the clothes" (Denisov 2015: 168).

In the Turkish period of the Nekrasov Cossack history, children had no opportunity to wear traditional clothes all the time either. At school, they had to wear a special uniform. The girls wore the uniform over the traditional shirt. Occasionally, girls could wear pants underneath their shirts in wintertime, which was not typical of traditional Cossack female costume.

During this time, both regular and irregular innovations emerged in the costume of this ethno-confessional group even before their return to Russia. But the Cossack culture changed much more radically after their homecoming. The last group returned to the Soviet Union in 1962.

In a short time, the Nekrasovites' traditional costume was no longer part of everyday existence. The traditional costume remained in use only as a festive or ritual dress. There were several reasons for this shift.

When the Nekrasov Cossacks were in an environment surrounded by people of many other cultures and religions, they made efforts to keep their cultural traditions. Costumes and aspects of cultural performance took on the weight of law as a way of maintaining their unique identity. Once the Nekrasov Cossacks returned to Russia, they did not preserve their traditions with as much care. Consequently, much of their traditional practices and costumes gave way to the processes of assimilation in a relatively short time. 
Secondly, the respondents reported that the climate in Russia was different from that in Turkey: Russian winters were colder and summers were hotter. The respondents said that they abandoned traditional clothes because of the differences in climate.

Partly, changes were caused by the very fact of migration: the Turks forbade the Nekrasov Cossacks to transport the jewelry and coin decorations across the border. They had to sell them or just leave all of them in Turkey. Later in Russia, they never renewed the tradition to decorate their costumes with coins.

And, finally, up to the time of the Cossacks return to Russia, the Russian traditional costume had been completely lost in the south of Russia. It was replaced by a unified urban costume. The bright costumes of the Nekrasov Cossacks were completely different from the local ones. The newcomers were perceived as strangers. The respondents said that the locals called them Turks. This perception of the Nekrasov costume as an alien one resulted in an interesting ritual practice. In the first year after moving to Russia, the Nekrasov Cossacks wore the traditional wedding costume with the original headdress (kichka) during Christmas guising; the locals thought it was ridiculous. ${ }^{7}$ Thus, the rejection of the traditional costume happened gradually, partially through the pressure of the new social environment.

Other elements of the Nekrasov Cossack culture also disappeared to a certain extent.

The changing economy transformed traditional workways: fishermen became trained as planters, and the new life according to the collective farm laws influenced changes in the rhythm of life. Marriages outside the group made the society less monolithic than before. As it happened in other parts of Russia, in the regions of the new Cossack habitat - namely in Krasnodar and Stavropol krays - young people left their homeland to study and work in other cities and other regions of the country. All these factors contributed to the rapid transformation of the culture of the Nekrasov Cossacks. As one of my interviewees put it, "There we followed all the customs. It is here, in Russia, where everything is lost." 8

In the sphere of family rituals, traditional clothing gradually became of secondary importance. In the 1970s-1990s, the Nekrasovites (mostly women) wore the traditional costume for the wedding ceremony in the church, and urban-style dresses for a secular registration of the marriage. At the same time, female headgear was simplified. Photographs from the Soviet period, kept in the Nekrasovites' archive, show that in the mentioned period a bride would simply cover her head with a kerchief and would not use the elaborate headdress of kichka, soroka, and pozatyl'nik. 
Considerable differences existed in the notions of dress appropriate for funeral ceremonies in southern Russian and Nekrasovites' societies. In Stavropol villages, there was a tradition for visitors to dress in dark colors. While the Cossacks wore everyday (but not festive) clothes on these days, these clothes had the same bright colors as the festive dress. Under the influence of the local 'dress code', the Nekrasovites gradually ceased to wear the traditional costume at funerals. A ban was imposed on the traditional costume dress for widows during the three years following the death of the husband. Among the funeral customs connected with costumes today, only the tradition of dressing the deceased in traditional clothes and covering him or her with a special white shroud (savan) have remained unchanged.

Calendrical festivals constitute the part of the tradition where the traditional costume is preserved better than at any other time, particularly involving Easter and the patronal feasts in the Nekrasovites' villages.

\section{NEKRASOVITES' FESTIVE CLOTHES AS A HERITAGE OBJECT}

Despite the narrowing of the scope of the traditional costume use in the natural context, it has become a symbol of the whole Nekrasov Cossack culture in newly emerging contexts.

It appears that researchers and media representatives, such as journalists, have had a significant effect on the form in which the Cossack culture exists today. Since the time of the Cossack return to their homeland and up through the present day, researchers and media people have frequently visited the villages. During the Soviet period, studies of certain aspects of culture, such as folk religion, were banned. Therefore, scholars focused on those forms of culture that were not in dissonance with the ideological program of the Soviet state. There were studies on the legends and songs, describing the rebellion under the leadership of Ignat Nekrasov and Kondraty Bulavin, and studies on fairy tales. Costume was the part of the material culture that attracted the most attention of ethnographers and the mass media. Journalists were interested, primarily, in its exoticism. The texts that emerged from these studies and contacts often emphasized that Nekrasov Cossack traditional clothes had been preserved without changes since the 18th century. Images of the Cossack women often appeared, and still do, on the covers of magazines and journals, in case the articles within describe Nekrasov Cossack culture and traditions.

There is one more interesting practice dealing with the traditional costume. There is a widespread practice of dressing guests - members of the ethnographic, folk, and ethno-musicological expeditions and journalists - in the Nekrasovites' 


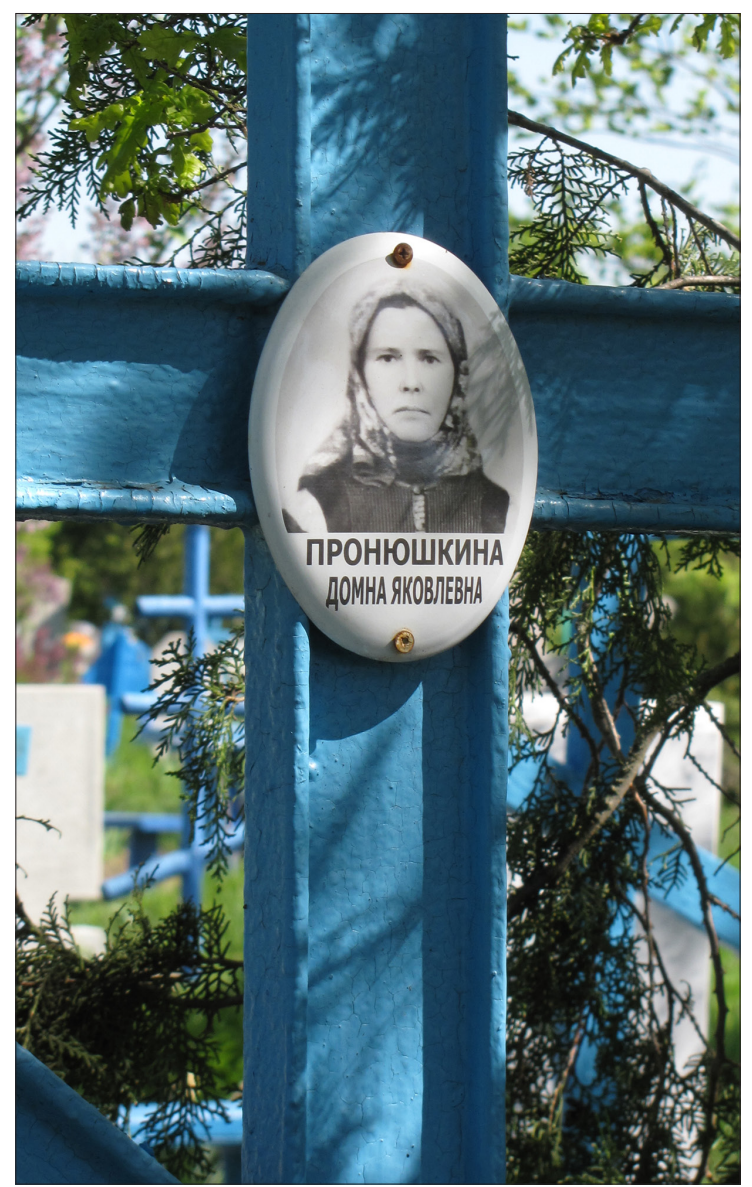

Figure 5. Photograph of a Nekrasov Cossack woman in the national costume on a gravestone at the cemetery of Novokumskii village, Stavropol kray, Russia. Photograph by Nina Vlaskina 2010.

clothes, which can be regarded as a way to overcome the boundaries between 'our' and 'alien'. ${ }^{9}$

Having been excluded from the sphere of everyday life, the traditional costume started to play an active role in the memorial sphere. Making costumes for store-bought dolls became one of the forms of transmitting the traditional knowledge about dressing. This becomes relevant in a situation when children live apart from their parents and grandparents, and far away from their homeland. These kinds of dolls are primarily made by the older generation of the Nekrasov Cossack women. They used, and still do, their old costumes and parts of the garments for that purpose. The parts were available because the Nekrasovites preserved not only complete sets of costumes, but also their components, such as sleeves or hems of shirts. Such costumed dolls are not only gifts for children, but can also be left in the homes of their makers. Today dolls decorate the interiors of a number of Nekrasovites' houses.

To my mind, the actualization of the memorial function can be seen in some innovations in the funeral ceremony. I discussed these rituals above, and would like to return to them in another context. While earlier on the Nekrasov Cossacks did not care for the grave after the funeral - neither by putting gravestones nor by decorating the grave - today, according to our informants, the Nekrasovites 
have come to accept Russian practices. Today one can see crosses and monuments on the Nekrasovites' graves, similar to the graves of other residents of the Stavropol kray. In this case, it is important that they are often decorated with photographs in which the deceased are depicted in their traditional dress. It seems that this new custom can be interpreted as a means of emphasizing the national identity or the national self-reflection.

Another context in which the Nekrasov costume acquires the memorial function is the activity of official institutions. Today in Russia the traditional clothing of the analyzed group is widely used in the public heritage policy. It is an obligatory element of museum exhibitions devoted to the culture of the Cossacks. The Nekrasov Cossack costume is exhibited in museums of those areas where they resettled, in the Novokumskii village of Stavropol kray, and it is also part of the museum exhibitions in the Rostov region (museums of Rostovon-Don, Novocherkassk, Starocherkasskaya, and Taganrog) and in Krasnodar. I should mention here that the Cossack costume is exhibited in museums only partially. For example, the workwear of a Nekrasovite is absolutely absent in the museum text and would not be preserved by the Cossacks themselves. Parts of female headgear, such as kokoshnik, as well as certain winter out-

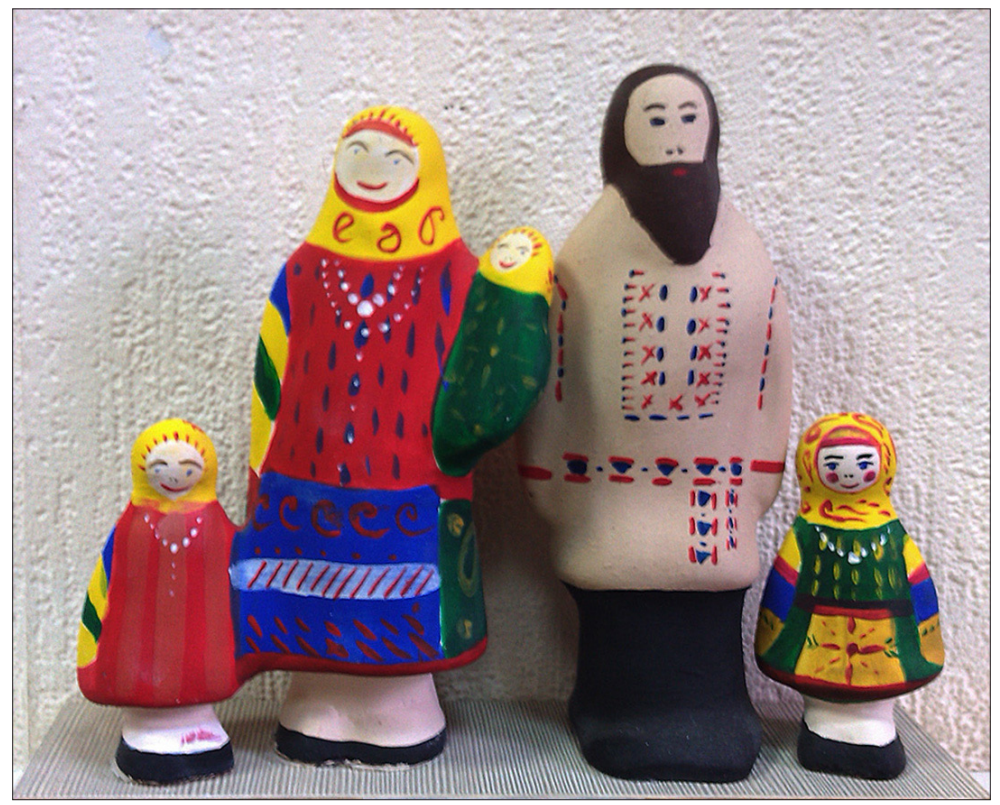

Figure 6. Painted clay dolls given to the author as a souvenir from the Stavropol Regional Museum of Fine Arts in 2012. 
erwear, were also just mentioned by respondents, but were never shown in any official or private context. These facts draw the observer to the conclusion that, gradually, the image of the costume is constructed where the elements of everyday clothes are vanishing and the main elements most abundant in various collections will survive.

This image of the Nekrasov Cossack costume is actively used in creating souvenirs. The manufacturing of souvenir dolls based on traditional designs has been recently established in the area. The Stavropol artists make stylized clay dolls depicting the Nekrasov Cossacks. Cossack dolls and Cossacks themselves wearing traditional costumes are also painted on souvenir badges.

After returning to Russia, the Nekrasovites were faced with another phenomenon of the Soviet cultural life. There were houses and palaces of culture, cultural workers and folk groups. In the $1980 \mathrm{~s}$, a folk ensemble was organized in the Nekrasov Cossack community, too. The Moscow Conservatory and Vera Medvedeva (Nikitina) did their best to organize international and Russian tours for this folk group. The ensemble still exists; it was, and still is, very popular. Through its performances, the costume of the Nekrasov Cossacks has become well known far beyond the habitat of this ethnic and religious group, in many regions of Russia (from Novosibirsk and Yekaterinburg to Moscow and St. Petersburg), and in other countries (for example, the USA). The consequence of this fame is the fact that the Nekrasovites' costume begins to be perceived as a symbol of an authentic tradition. As a result, members of folklore groups from other regions choose these Nekrasov Cossack clothes for their own performances, because for them it represents an authentic Russian costume, which was preserved without changes since the 18th century when the Nekrasovites left the Don region.

\section{CONCLUSIONS}

Today the national costume is the best preserved one among all the cultural expressions of the Nekrasov Cossacks. During the existence of this ethnic group, it underwent several stages of changes. Firstly, the costume of this ethno-confessional society absorbed different ethnic elements of both Slavic and Turkic cultures during the late 17 th - early 18 th centuries; then, the eastern influence was enhanced during the Turkish period of the Cossack life, though the core elements of the costume remained unchanged. Finally, after the Nekrasovites' return to their homeland, the composition of the traditional garments was simplified and changed its functions. 
In the USSR, at first, brightness and exotic appearance were the reasons to oppose the Nekrasovites and other inhabitants of the Stavropol and Krasnodar krays, and this prevented integration. But later on the costume of the Nekrasov Cossacks was met with admiration by journalists, researchers, and museum specialists. The important point was the fact that, unlike other artifacts, costumes, especially the female ones, were kept in Nekrasov families in large numbers. The dowry of each girl could contain up to 30 full costume sets, a significant part of which the Nekrasovites managed to bring to Russia.

The constant academic enquiries about these elements of culture produced unexpected consequences. With each new arrival of scientists and journalists, the tradition bearers more and more readily reproduced their knowledge about the costume in a detailed way. The respondents of middle and older age provided profound descriptions of the costume details, told their names and depicted their characteristics. The interviews often included self-reflection by the informants about the importance of preserving their traditional clothing.

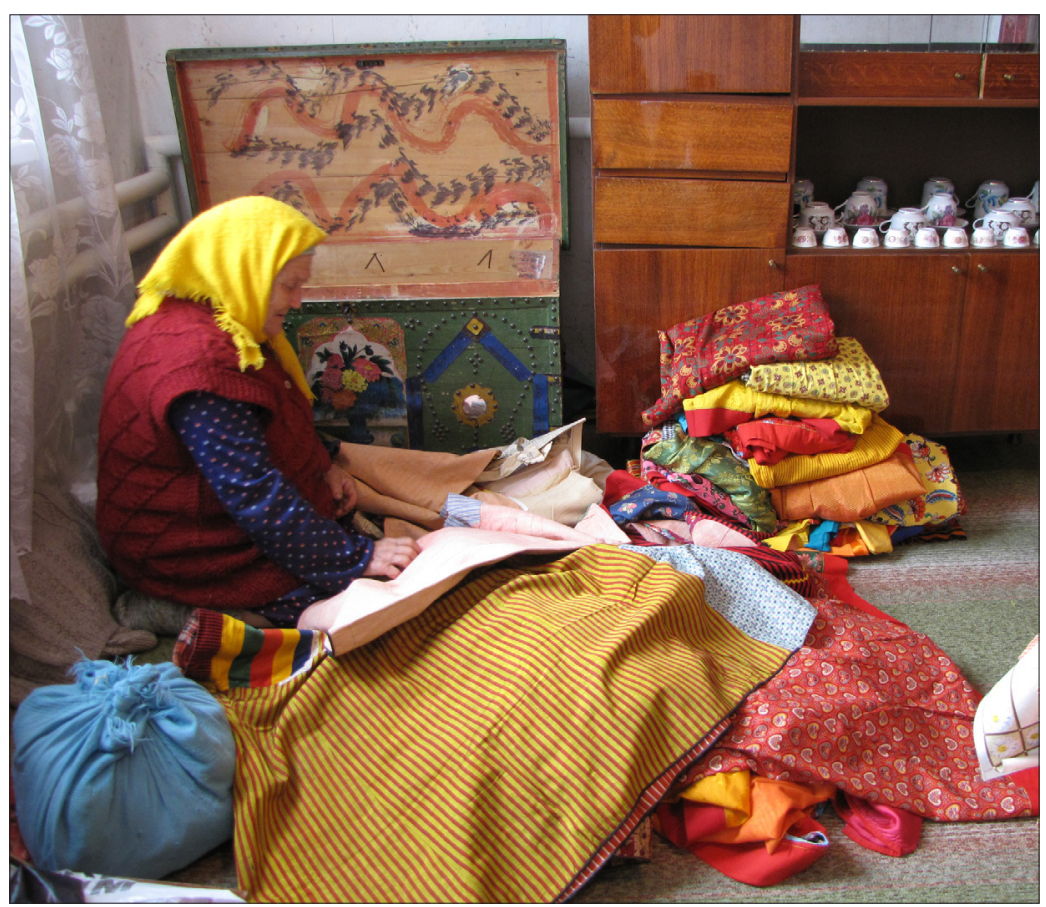

Figure 7. Evdokia Aralova and her national costumes. Brinkovskaya village, Krasnodar kray, Russia. Photograph by Nina Vlaskina 2016. 
Through the promotional activity of many scientific, educational, and governmental institutions, the Nekrasovites' costume became widely known both in its original variants and in the images, copies, and stylization, functioning as a souvenir. As a result, the festive costume of the Nekrasov Cossacks became a symbol of the heritage of the group and has continued to live its life, both inside and outside the Cossack community.

This case can serve as an example of the transformation of ethno-religious tradition into a heritage object. It is the type of transformation in which one element of culture comes to the fore, the one that has been preserved better or is more in demand for whatever reasons. Values and meanings are reaffirmed, and one element of culture begins to speak as an advocate of culture in general, while other elements of culture, omitted and irrelevant in the context of the changed circumstances, are doomed to oblivion.

\section{ACKNOWLEDGEMENTS}

This article is part of the research project of the Institute for Social and Economic Research and Humanities of the Southern Scientific Center of the Russian Academy of Sciences, No. 0260-2014-0006, titled Istoriko-kul'turnoe nasledie narodov Iuga Rossii $v$ usloviiakh modernizatsii (Historical and Cultural Heritage of the Peoples in the South of Russia in Modernization Context). I would like to express my thanks to Marija Gačić, Valeria Kolosova, and Irina Sedakova, who provided me with specialized researches in Bulgarian and Croatian, and also to Zilia Estrada for proofreading the article and for constant encouragement.

\section{NOTES}

1 See further the article by Cristina Clopot, Weaving the Past in a Fabric: Old Believers' Traditional Costume in the present volume.

2 See further the article by Alexander Novik and Andrey Sobolev, Traditional Wedding Costume of the Mrkovići in Montenegro: Between Real Heritage and Folk Construction (Materials of the Russian Expeditions in 2012-2014) in the present volume.

${ }^{3}$ Interview of Natalya Bondarenko and Lidia Siparova with Iakov Pushechkin, born in 1933, recorded in Novokumskii village, Stavropol kray, in 2010.

4 The History of "Kutnu" Fabric Weaving 2011. Available at http://www. ipekyolununustalari.org.tr/index.php?option=com_content\&view=article\&id=89\&It emid=227\&lang=en, last accessed on October 20, 2016. 
5 Most of these etymologies were identified by Olga Serdiukova (2005).

${ }^{6}$ See the article by Alexander Novik and Andrey Sobolev in the present volume.

7 Interview of Nina Vlaskina and Natalia Arkhipenko with Domna Shkodrina, born in 1931, recorded in Novokumskii village, Stavropol kray, in 2010.

8 Interview of Nina Vlaskina with Nikon Banderovsky, born in 1940, recorded in Malosadovyi village, Stavropol kray, in 2010.

9 Irina Sedakova mentioned the same situation in her Bulgarian expeditions while giving her presentation, Clothes as Symbolic Objects and Signs in the Ritual Time of the Slavic Childbirth Customs, at the SIEF Congress in 2015. Also, Anamaria Iuga describes the mentioned behavioral pattern in her article "Contemporary Traditional Clothing in Maramureş" in the present volume.

\section{REFERENCES}

Abramova, Tatiana 1997. Nekrasovskie rogatye kichki (k probleme identifikatsii odezhdy kazakov-nekrasovtsev). [Nekrasovites' Horned Kichkas (On the Issue of Identification of the Nekrasov Cossacks' Clothes).] Pamiati A.M. Listopadova: sbornik nauchnykh statei. [In Memory of A.M. Listopadov: Collected Articles.] Rostovon-Don: Gefest, pp. 82-90.

Abramova, Tatiana 2009. Traditsionnyi kompleks zhenskoi odezhdy v svadebnom obriade kazakov-nekrasovtsev. [Traditional Complex of Nekrasov Cossacks' Female Dress.] In: Z. Belaia (comp.) Kazaki-nekrasovtsy: sbornik materialov iz arkhivov Novokumskogo filiala muzeia izobrazitel'nykh iskusstv. [Nekrasov Cossacks: Collected Articles from the Archives of the Novokumskii Branch of the Museum of Fine Arts.] Stavropol: Stavropol'skii kraevoi muzei izobrazitel'nykh iskusstv, pp. 109-117.

Arkhipenko, Natalia \& Kalinichenko, Inna 2012. Materialy dlia izucheniia traditsionnogo kostiuma kazakov-nekrasovtsev: pogrebal'naia obriadovaia odezhda. [Materials for the Study of Traditional Nekrasov Cossacks Costume: Burial Ceremonial Clothes.] In: G. Matishov (ed.) Kazaki-nekrasovtsy: iazyk, istoriia, kul'tura: sbornik nauchnykh statei. [Nekrasov Cossacks: Language, History, and Culture: Collected Papers.] Rostov-on-Don: Izdatel'stvo IuNTs RAN, pp. 421-438. Available at http:// www.ssc-ras.ru/ckfinder/userfiles/files/Kazaki-nekrasovtsy\%202012\%20(i\%20 vklejka).pdf, last accessed on October 21, 2016.

BTS 2003 = Bol'shoi tolkovyi slovar' donskogo kazachestva. [The Big Dictionary of the Don Cossacks.] Moscow: Russkie slovari \& AST \& Astrel'. Available at http:// newstar.rinet.ru/ minlos/RussianDialects/Bol\%20tolk\%20slovar'\%20don\%20 kazachestva.pdf, last accessed on October 21, 2016.

Denisov, Nikolai 2015. Staroobriadcheskaia bogosluzhebno-pevcheskaia kul'tura: voprosy tipologii. [The Old Believers' Culture of Worship and Singing: Issues of Typology.] Moscow: Progress-Traditsiia. 
Fradkina, Nelli \& Novak, Lidia 1986. Starinnyi donskoi kazachii kostium XVII-XIX vekov. [The Ancient Don Cossack Costume of the 17th-19th Centuries.] In: Donskoi narodnyi kostium: $O$ sozdanii stsenicheskogo kostiuma na osnove donskoi narodnoi odezhdy. [Don Folk Costume: On the Design of the Scenic Costume on the Basis of the Don Folk Clothes.] Rostov-on-Don: Rostovskoe knizhnoe izdatel'stvo, pp. $32-40$.

Hamilton, William J. 1842. Researches in Asia Minor, Pontus, and Armenia; with Some Account of Their Antiquities and Geology. In two volumes. Vol. II. London: John Murray. Available at https://archive.org/details/researchesinasi01hamigoog, last accessed on October 21, 2016.

Ibrahimzade, Kemal \& Gusach, Irina 2015. Nekrasov kazaklarının geleneksel giysileri ve Tokat Yazmaları: Rusya müzelerinden örnekler. [Nekrasov Cossacks' Traditional Clothes and Tokat Fabric Print Designs on Hand Printed Samples from the Russian Museums.] Osmanlı Mirası Araştırmaları Dergisi / Journal of Ottoman Legacy Studies, Vol. 2, No. 2, pp. 26-37. Available at http://www.osmanlimirasi. net/dergi//3-nekrasov-kazaklarinin-geleneksel-giysileri-ve-tokat-yazmalarirusya-muzelerinden-ornekler-ss-26-37201504.pdf, last accessed on October 21, 2016.

Ivanov-Zheludkov, Vasily 1866. Russkoe selo v Maloi Azii. [Russian Village in Asia Minor.] Russkii vestnik, Vol. 63, pp. 413-451. Available at http://iht.univ.kiev.ua/ library/russkiy_vestnik/1866_63_russkiy_vestnik.pdf, last accessed on October 21, 2016.

Johnson, Patricia White 1983. Dress and Acculturation among the Russian Old Believers in Oregon. Diss. (MA Thesis). Unpublished. University of Oregon, Canada. Available at https://ir.library.oregonstate.edu/xmlui/handle/1957/7891, last accessed on October 21, 2016.

Kašpar, Libuše 1987. Novac u funkciji nakita u Karlovačkom području. [Money as Jewelry in the Karlovac Region.] Etnološka tribina / Journal of Croatian Ethnological Society, Vol. 17, No. 10, pp. 33-36. Available at http://hrcak.srce.hr/80334, last accessed on October 21, 2016.

Lipinskaya 2011 = Lipinskaia, Viktoria 2011. Nekrasov Cossacks. In: Viktoria Lipinskaia (ed.) Russkaia odezhda: Istoriko-etnograficheskije ocherki. [Russian Clothes: Historical and Ethnographic Essays.] Moscow: Indrik, pp. 394-401. Available at http://ebook.indrik.ru/products/russkaya-narodnaya-odezhda-istorikoetnograficheskie-ocherki, last accessed on October 25, 2016.

Mac Farlane, Charles 1850. Turkey and Its Destiny: The Result of Journeys Made in 1847 and 1848 to Examine into the State of That Country. In two volumes. Vol. 1. Philadelphia: Lea and Blanchard. Available at https://books.google.ru/books/about/ Turkey_and_Its_Destiny_the_Result_of_Jou.html?Id=1zjmaaaacaaj\&redir_ esc=y, last accessed on October 21, 2016.

Mainosskie kazaki 1899 = Mainosskie kazaki i ikh zemlia. [Manyas Cossacks and Their Lands.] In: Kievskaia starina, Vol. LXVI, pp. 104-107. Available at http://www. runivers.ru/bookreader/book479965/\#page/613/mode/1up, last accessed on October 25, 2016. 
Maslova, Gali 1956. Narodnaia odezhda russkikh, ukraintsev, belorusov v XIX nachale XX v. [Folk Clothes of the Russians, Ukrainians and Byelorussians in the 19th - the Early 20th Centuries.] In: S. Tokarev (ed.) Vostochnoslavianskii etnograficheskii sbornik. [Eastern Slavic Ethnographic Miscellany.] Moscow: Izdatel'stvo Akademii nauk SSSR, pp. 541-757. Available at https://vk.com/doc 4410839_341589901?hash=d7e36b78f4aa5d710d\&dl=8c1665b691d55f7317, last accessed on October 21, 2016.

Minorsky 1902 = Minorskii, Vladimir 1902. U russkikh poddannykh sultana. [Among Russian Subjects of the Sultan.] Etnograficheskoe obozrenie, No. 2, pp. 31-86. Available at https://archive.org/details/eo_LIII_1902_full, last accessed on October 21, 2016.

Naslednikova, Venera 1969. Istoria na bulgarskia kostium. [The History of Bulgarian Costume.] Sofia: Nauka i izkustvo. Available at https://vk.com/doc173190536_ $437677802 ? \mathrm{hash}=686 \mathrm{e} 7 \mathrm{~d} 0 \mathrm{c} 0 \mathrm{e} 7 \mathrm{be} 6 \mathrm{f} 670 \& \mathrm{dl}=07913 \mathrm{bdefd} 2 \mathrm{c} 8 \mathrm{~d} 7 \mathrm{~d} 5 \mathrm{~b}$, last accessed on October 21, 2016.

Neikova, Ruzha n.d. Sreburnata zhena: Etnokulturni paraleli. [Silver Woman: Ethnocultural Parallels.] Available at http://www.bulgari-istoria-2010.com/booksBG/R_ Neikova_Srebyarnata_zhena.pdf, last accessed on October 20, 2016.

Öğuz, Öcal (ed.) 2008. Turkey’s Intangible Cultural Heritage. Ankara: Ministry of Culture and Tourism.

Serdiukova, Olga 2005. Slovar' govora kazakov-nekrasovtsev. [The Dictionary of the Dialect of the Nekrasov Cossacks.] Rostov-on-Don: Izdatel'stvo Rostovskogo gosudarstvennogo universiteta. Available at http://library.kazachiy-hutor. ru/uploads/2016/04/serdjukova_slovar_kazakov_nekras.pdf, last accessed on October 21, 2016.

Shchepotiev, V. 1895. Russkaia derevnia v Aziatskoi Turtsii. [Russian Village in Asian Turkey.] Vestnik Evropy, Vol. 8, pp. 562-583. Available at https://commons. wikimedia.org/wiki/File:\%D0\%92\%D0\%B5\%D1\%81\%D1\%82\%D0\%BD\%D0\%B8 $\% \mathrm{D} 0 \% \mathrm{BA} \% \mathrm{D} 0 \% 95 \% \mathrm{D} 0 \% \mathrm{~B} 2 \% \mathrm{D} 1 \% 80 \% \mathrm{D} 0 \% \mathrm{BE} \% \mathrm{D} 0 \% \mathrm{BF} \% \mathrm{D} 1 \% 8 \mathrm{~B} \_1895 \_174 \_\%$ D0\%93\%D0\%B0\%D1\%80\%D0\%B2\%D0\%B0\%D1\%80\%D0\%B4.pdf, last accessed on October 21, 2016.

Smirnov, Iakov 1896. Iz poezdki po Maloi Azii: U nekrasovtsev na ostrove Mada, na Beisheirskom ozere, Gamid-Abadskogo sandzhaka, Koniiskogo Vilaieta. [From the Journey in Asia Minor: Among the Nekrasovites on the Mada Island at Beysehir Lake of Gamid-Abad Sanjak and Konia Vilayet.] Zhivaia starina, Vol. 1, pp. 3-31. Available at http://lib.rgo.ru/dsweb/Get/Resource-705/ruprlib12047266. pdf, last accessed on October 24, 2016.

Sukhorukov, Vassily 1892. Obshchezhitie donskikh kazakov v XVII i XVIII stoletiiakh: Istoricheskii ocherk. [The Common Life of the Don Cossacks in the 17th and 18th Centuries: An Historical Essay.] Novocherkassk: Oblastnaia voiska Donskogo tipografiia. Available at https://s3.netangels.ru/books/\%D0\%94\%D0\%BE\%D0 $\% \mathrm{BD} \% \mathrm{D} 1 \% 81 \% \mathrm{D} 0 \% \mathrm{BA} \% \mathrm{D} 0 \% \mathrm{~B} 8 \% \mathrm{D} 0 \% \mathrm{~B} 5 \% 20 \% \mathrm{D} 0 \% \mathrm{BA} \% \mathrm{D} 0 \% \mathrm{~B} 0 \% \mathrm{D} 0 \% \mathrm{~B} 7 \%$ D0\%B0\%D0\%BA\%D0\%B8/Popov-Obshegitie\%20kazakov.pdf, last accessed on October 25, 2016. 
Taş, Ela 2015. Belt Buckles Dated to the Nineteenth Century. In: Khalilli, Fariz (ed.) IV International Congress of Eurasian Archaeology. 1-5 October 2012. Baku: AGSU, pp. 89-93. Available at http://farizkhalilli.az/userfiles/ICEA\%202012\%20 AGSU-a4\%20Final\%202015\%20web\%202(1).pdf, last accessed on October 24, 2016.

Veleva, Maria (comp.) 1950. Bulgarski narodni nosii i shevitsi. [Bulgarian National Costume and Embroidery.] Sofia: Nauka i Izkustvo.

Zhukova, Lydia \& Bandurina, Svetlana 1986. Odezhda kazakov-nekrasovtsev. [Nekrasov Cossacks' Clothes.] In: Donskoi narodnyi kostium: O sozdanii stsenicheskogo kostiuma na osnove donskoi narodnoi odezhdy. [Don Folk Costume: On the Design of the Scenic Costume on the Basis of the Don Folk Clothes.] Rostov-on-Don: Rostovskoe knizhnoe izdatel'stvo, pp. 54-63. 